Scientific Journal of Silesian University of Technology. Series Transport

Zeszyty Naukowe Politechniki Śląskiej. Seria Transport

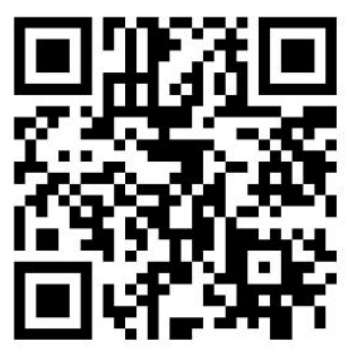

Volume 100

2018

p-ISSN: 0209-3324

e-ISSN: 2450-1549

DOI: https://doi.org/10.20858/sjsutst.2018.100.14

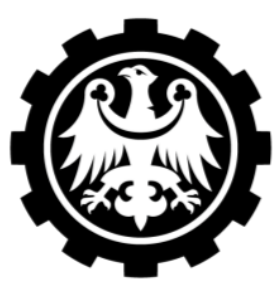

Silesian

University of Technology

Journal homepage: http://sjsutst.polsl.pl

Article citation information:

Rutkowski, M. Main legal recommendations for the road network and its maintenance in the Tsarist Russian Empire following the initial wars of Nicholas I. Scientific Journal of Silesian University of Technology. Series Transport. 2018, 100, 165-180. ISSN: 0209-3324. DOI: https://doi.org/10.20858/sjsutst.2018.100.14.

Marek RUTKOWSKI ${ }^{1}$

\title{
MAIN LEGAL RECOMMENDATIONS FOR THE ROAD NETWORK AND ITS MAINTENANCE IN THE TSARIST RUSSIAN EMPIRE FOLLOWING THE INITIAL WARS OF NICHOLAS I
}

Summary. The aim of this article is to present the main proposals of two Tsarist Russia transportation laws, introduced in the spring of 1833 and at the turn of 1834. Both laws were prepared by Count Dmitry Bludov, then Minister of the Interior, and finally accepted by Tsar Nicholas I himself. Their main goal was to properly develop the Russian transportation network, but not too rapidly and without consuming a considerable amount of State Treasury funds.

Keywords: Russian transportation laws; tsarist transport administration; Russian road network; corvée in Tsarist Russia; 19th century.

\section{INTRODUCTION}

On 20 November/2 December 1809, a new organization responsible for transportation issues was established under the name of the Main Board for Roads of Communication and

\footnotetext{
${ }^{1}$ Department of Social Sciences, University of Informatics and Economy, Society of Common Science in Olsztyn, Jagiellońska 59 Street, 10-283 Olsztyn. Email: rutmarek@gmail.com.
} 
Public Edifices ${ }^{2}$. In response, Tsar Alexander I emphasized the magnificent role of all sorts of communication in terms of developing and increasing national "wealth" and "fame" 3 Unfortunately, due to a few turbulent years and many other obstacles, it proved relatively hard to achieve this ambitious goal to rapidly grow the transportation network within the state's borders. Nevertheless, the highest authorities still planned and insisted on further endeavours in this field of the national economy, as reflected, for example, in Alexander's "tsar's notes" regarding roads, which were finally approved in 1817, or the order of Tsar Nicholas I of 2/14 March 1826.

The Turkish and Polish wars of the late 1820s and the beginning of the 1830s clearly demonstrated, for both military and economic reasons, the pressing need of real and steady state engagement in the somewhat neglected process of creating a tsarist transportation network. Related to this phenomenon, in 1832, a special permanent committee was established "for the provision of roads in the State", while St Petersburg's State Council issued a formal opinion, which partly related to the problem of road surveillance and repairs ${ }^{4}$. Furthermore, in connection with formal opinion, St Petersburg's State Council basically re-evaluated the field of road and transport legislation in Tsarist Russia in 1833. At that time, the then Minister of the Interior the Russian Empire, Count Dmitry Bludov, finally presented his proposals for regulations regarding the formal means of performing road duties. These were then initially approved by Tsar Nicholas I himself on $24 \mathrm{March} / 5$ April $1833^{5}$ as the so-called "Basic rules of building and maintaining roads in the (Russian) state" 6 .

The task of taking some preliminary steps in improving the Russian transportation network was not competed at this stage until new additional laws were released. As it turned out, after 1833, the then Minister of the Interior of the Russian Empire, Count Bludov ${ }^{7}$, had presented new proposals for regulations regarding the means of performing road duties, which were approved on 5 April (referring to the Gregorian calendar) by Tsar Nicholas I. A new statement by the Council of State "on the measures of realization of roads duties" was approved formally by Tsar Nicholas I on 29 December 1833/10 January 1834. It is worth mentioning that the Council of State - operating jointly on this occasion within the framework of its two departments (legal and economic) and thereafter working on the new law in the administrative body of the General Assembly - found the new provisions at stake to be extremely effective and useful, thus enabling their formal announcement. According to Russian legislators, the main reason for issuing such a positive deliberation was their awareness of the existence of an obvious necessity to set "permanent" rules for the execution of transportation duties, which Count Bludov, as the Minister of the Interior, consequently proposed in a transparent manner and "with reasonable prudence".

\footnotetext{
${ }^{2}$ Full Digest of Laws of the Russian Empire Since 1649. Vol. 30: 1808-1809. St Petersburg: Printing House of Second Division of His Imperial Majesty's Chancery. Full Digest of Laws of the Russian Empire 1830: 13051339. St Petersburg: Printing House of Second Division of His Imperial Majesty's Chancery.

${ }^{3}$ Full Digest of Laws of the Russian Empire Since 1649. Vol. 30: 1808-1809. Saint Petersburg: Printing House of Second Division of His Imperial Majesty's Chancery. Full Digest of Laws of the Russian Empire 1830: 1305. St Petersburg: Printing House of Second Division of His Imperial Majesty's Chancery.

${ }^{4}$ Petersburg Weekly: Official Gazette of Kingdom of Poland. 21 February 1834, 11: 65.

${ }^{5}$ Petersburg Weekly: Official Gazette of Kingdom of Poland. 18 February 1834, 10: 61.

${ }^{6}$ Full Digest of Laws of the Russian Empire 1834: 180-183. St Petersburg: Printing House of Second Division of His Imperial Majesty's Chancery. Petersburg Weekly: Official Gazette of Kingdom of Poland. 21 February 1834, 11: 65 .

${ }^{7}$ N. Varadinov 1862. History of the Ministry of the Interior: 30-52. St Petersburg: Printing House of Ministry of the Interior.
} 
Nonetheless, the supreme state councillors sought to improve the newly presented laws by adding supplements. In the opinion of the Council of State, it was inevitable, as well as special supplements, to add explanatory notes to the new act prepared by Count Bludov, partly due to keeping up with the spirit and core sense, as well as wording, of the already introduced regulations in the field of Russian roads ${ }^{8}$.

Finally, on 25 January/6 February 1834, the First Department of the Governing Senate released a specific order, which was strictly combined with an official announcement by the Council of State "on the measures of realization of roads duties"9.

In turn, mostly after the experiences of the Turkish and especially the Polish Wars, while Russian authorities under Tsar Nicholas I wholly acknowledged (at least formally) the unique necessity for a proper transportation network in the country, two extraordinary bills were released, of equal importance. The first dealt with the "Basic rules of building and maintaining roads in the (Russian) state", while the other related to "the measures of realization of roads duties". These are described in the following two parts of this article.

\section{2. "THE ESSENTIAL REGULATIONS FOR BUILDING AND MAINTAINING ROADS IN THE (RUSSIAN) STATE” OF 24 MARCH/6 APRIL 1833}

Formally accepted by the tsar on $24 \mathrm{March} / 5$ April1833, these so-called "Basic rules of building and maintaining roads in the (Russian) state", coincided with several important factors, among which the most significant solutions concerned the very division of roads in the Russian Empire into five different classes. This division included the following types of routes: a) main roads; b) great roads; c) ordinary roads, that is, postal roads between individual governorates; d) district ("poviat") roads, including typical postal and commercial routes; e) rural and field roads.

For the main routes, the Law of 5 April 1833 recognized: a) the route leading from St Petersburg to Moscow, which at the time of the announcement of the bill was "almost already completed"; b) the route from Moscow to Nizhny Novgorod, which - as it was written in February 1834 - "[was] already outlined"; c) the road from Moscow via Gzack (Gżack) to Smolensk; d) the route from St Petersburg to Riga; e) the road from St Petersburg via Dyneburg (Latvian: Davgavils; Polish: Dzwińsk ) to Kaunas (then Kowno), whose communication track was, in 1834, described as "already under preliminary stage of construction"; f) the road leading from Moscow via Smolensk and Mogilev on the Dnieper (Polish: Mohylew) to Brest-Litovsk (Polish: Brześć Litewski). All these roads were to be built and maintained with the support of the State Treasury, i.e., from public funds. This meant, in practice, that everything in this regard was to be paid by St Petersburg's Main Board for Roads of Communication and Public Edifices, while transferring, for this purpose, a state tax collection amounting to 25 kopecks "for one soul [individual taxpayer]" per year.

\footnotetext{
${ }^{8}$ Petersburg Weekly: Official Gazette of Kingdom of Poland. 21 February 1834, 11: 65.

${ }^{9}$ Full Digest of Laws of the Russian Empire 1834: 817-820. St Petersburg: Printing House of Second Division of His Imperial Majesty's Chancery. Petersburg Weekly: Official Gazette of Kingdom of Poland. 18 February 1834, 10: 61 .
} 


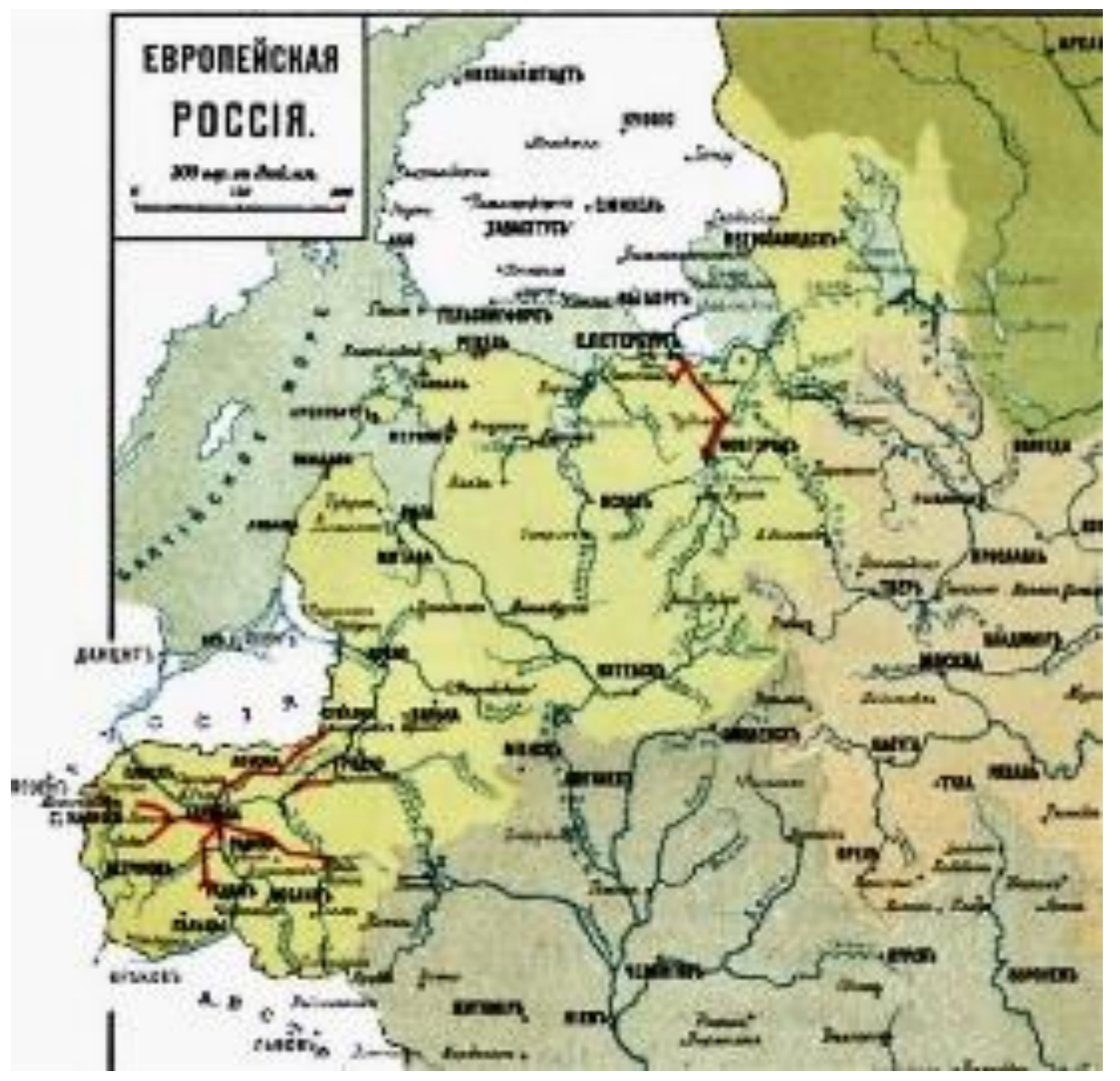

Fig. 1. The actual structure of main roads built in the Tsarist Russian Empire under the rule of Alexander I (until 1825) ${ }^{10}$

As mentioned above, the second most important category of Russian routes concerned "the great roads". According to the Act of April 1833, they included: a) the Belarussian route, leading from St Petersburg via Kiev to Odessa on the shores of Black Sea; b) the road going from Riga via Šiauliai (then Szawle) in Samogitia to Taurage (then Taurogi), at the border with East Prussia; c) the route leading from the Taurogien route via Vilnius (then Wilno) and Grodno to Białystok, at that time, the capital of a special non-governorate separate administrative district, near Tsarist Russia's formal border with Congress Poland; d) the road leading from Kiev via Zytomyr (then Żytomierz) and Dubno to Radivilov (then Radziwiłłow), near the border with Austrian Galicia (i.e., with the Austrian part of the partitioned Polish-Lithuanian Commonwealth); e) the road from Kiev via Chernihiv (Polish: Czernihów Siewierski), Kursk, Orel and Tula to Moscow; f) the route from Moscow to Jaroslav; g) the road from Moscow via Tula, Oriel, Nizyn (Polish: Nieżyn, on the territory of the former Seversk Principalities), Kiev, Zytomyr (then Żytomierz) and Dubno to - as previously mentioned - Radivilov (then Radziwiłłow; h) the communication track leading from Kursk, Kharkiv, Poltava and Kremieńczuk (Polish: Krzemieńczuk) on the banks of the Dnieper River to Odessa (it is worth mentioning that the legislators assumed, in 1833, that if reasonable circumstances occurred, a new branch of this track would be stretched out

\footnotetext{
${ }^{10}$ Kratkij istoriceskii ocerk razvitsia i deiatelnosci Vedomstva Putej Soobscenia za sto let jego soscestvovabia (1798 -1898 g.). 1898: 224 (not numbered). St Petersburg: Tipografia Vedomstva Putej Soobscenia.
} 
towards the Don River and the Caucasus Mountains; i) the route from Moscow to Ryazan; k) the track from Moscow to Kaluga; 1) the road from Riga via Polotsk (Polish: Połock), Vitebsk (Polish: Witebsk), Smolensk and Gżack to Moscow (here the option of directing this route with a straighter line was also taken into consideration, namely, the section via Sebezh (Polish: Siebież), Vielikie Luki (Polish: Wielkie Łuki), Rielyj and Gżack towards Moscow.

At the same time, in Article 4 of the formal Transportation Legislative Act of 5 April 1833, its authors stipulated the possibility of increasing the number of Russian Empire's most vital and important tracks, recognized as so-called "big routes". Similarly, the possibility was raised of an eventual change in the future of the general directions of newly built communication routes "according to [timely] requirements". In the future, both Count Bludov and, after signing the new law, Tsar Nicholas I himself saw the need or opportunity to build two such new routes, namely: a) the track leading from Mogilev (Polish: Mohylew) along the Dnieper River, via Zytomyr (then Żytomierz), Berdyczev (then Berdyczów) and Tulchyn (then Tulczyn) to Odessa and, "if necessary", a route leading from Balta via Dubossary (Romanian: Dubăsari), to Skulany in Bessarabia, right up to the border of Moldova ${ }^{11}$.

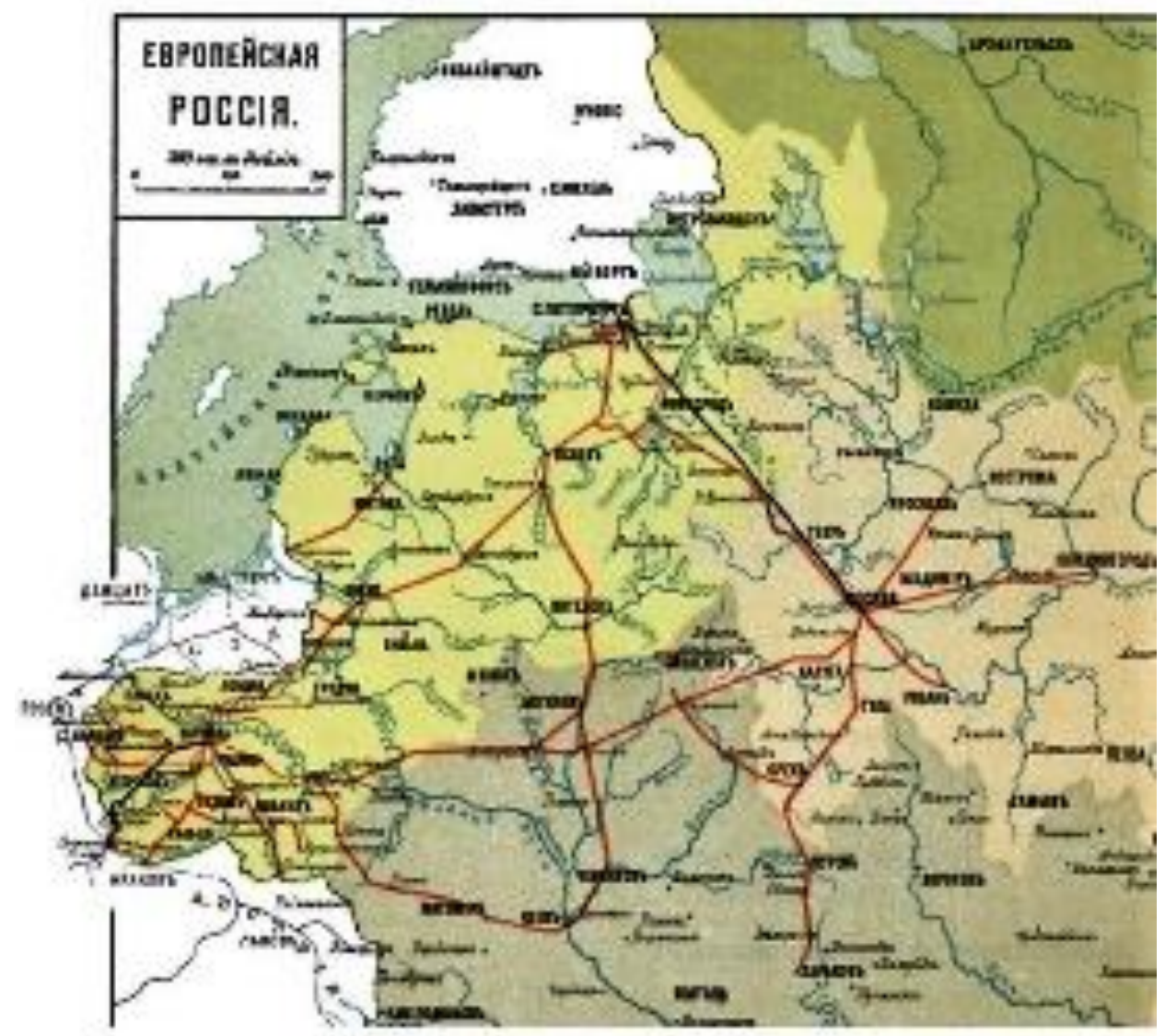

Fig 2. Main Roads built in Tsarist Russia in the time of Nicholas I (1825-1855) ${ }^{12}$

\footnotetext{
${ }^{11}$ Petersburg Weekly: Official Gazette of Kingdom of Poland. 25 February 1834, 12: 73.

${ }^{12}$ Ktatkij istoriceskij ocerk razvitsia i deiatelnosci Vedomstva Putej Soobscenia za sto let jego soscestvovabia (1798-1898 g.), 1898: 226 (not numbered). St Petersburg: Tipografia Vedomstva Putej Soobscenia.
} 
As for the construction of roads, Article 5 of the Act of April 1833 ordered the construction of roads of the chaussée type (i.e., in theory, paved roads) on all large tracks, which, however, were supposed "not to be very wide" and provided with only a "light" slope profile. The general rule was that the overall cost of construction of these communication routes should be "inexpensive", which in principle - and overwhelmingly contrary to general idea of formally building "chaussée roads" - forced the creation in some cases of earth-type communication routes (i.e., the construction of roads not of a paved type - namely, of the macadam system - but only made of "ground"). On same parts of these roads, it was necessary to construct - if only suitable conditions could be found - bridges made of bricks or even perhaps special types of bridges, made almost entirely of cast iron elements. At the same time, it was stipulated that, in those areas where the construction of planned roads could be associated with particular difficulties, it would be unnecessary to require builders to construct large embankments, which would normally serve as a solid basis for running communication routes. On the other hand, in the steppe areas, where building materials were generally hard to obtain or simply missing, Count Bludov recommended in 1833: a) to leave already existing roads "in the natural state"; b) not to plant among communication tracks any (significant number of) trees and other "adornments", or "embellishments". However, in difficult areas where it would presumably be impossible for typical travellers to determine their proper orientation during a winter blizzard, it seemed to be necessary to put up some road signs for directions or other orientation points; thus, dispersal at some distance from each clump of trees or even tree beds was ordered or the "sowing" (original description) of bushes. In the indigenous steppe areas, it was suggested to use for this purpose special sticks "hammered" into the ground or to heap mounds of earth or stone.

The Law of 5 April 1833 clearly stated that "great roads should be made at the cost of land obligations/taxations". The principles of burdening as well as charging the local administration and population with building the main communication routes of the Russian Empire were as follows. First of all, all highways had to be built under the general guidance of the governors of the governorates at stake and, similarly, under the main decision-making supervision of the Russian Ministry of the Interior. Quite surprisingly, it was stressed that these works were to be performed "unhurriedly" (sic). The very pace of transportation system building was dependent on the availability of state budget funds earmarked for road construction and extremely SO on the availability of a sufficient number of appropriately educated high-tech road and engineering personnel ${ }^{13}$. One could see here a form of direct reference to those individuals who had been formally educated at the St Petersburg Institute of Communication Roads (mostly road engineers) and were officially responsible for performing the duties of governorate road engineering staff ${ }^{14}$.

Secondly, the Act of April 1833 introduced a strongly common-sense rule, generally ordering maintenance and support for the current course of roads, while delimiting and building a new type transportation track network. The pre-eminent condition for pursuing such a procedure, however, involved some obvious economic and strategic considerations, i.e., the lack of the need for an overly important increase in the distances between individual

\footnotetext{
${ }^{13}$ Petersburg Weekly: Official Gazette of Kingdom of Poland. 25 February 1834, 12(13): 73.

14 Central Archives of Historical Record in Warsaw. Rada Administracyjna Królestwa Polskiego: 1832. Signature 24: 337-341. The problem was to be partially solved by including Polish engineers (namely, from the dependent regions of the Tsarist Russian Kingdom of Poland, where the Board for Roads and Bridges existed at the time) in the Tsarist Russian Corps of Land and Water Communications. The decision was announced by Warsaw's Administrative Council on 29 June 1832.
} 
significant towns on a given route. Generally, it was nonetheless recommended that, when choosing a route for newly built communication traction, one had to meet the pressing necessity to try to "straighten out all the major shortcomings and drawbacks of present roads". The legislators (namely, Count Bludov and finally Tsar Nicholas himself) also admitted that, previously, it happened too relatively often in the Russian Empire that, while delimiting communication routes - due to the appearance, in the course of a specific track, "not too important obstacles", which would be relatively easy to overcome - the directions of such communication routes were many times deviated significantly, thus extending the travel distances themselves. Under these circumstances, lawmakers did not fail in the spring of 1833 to emphasize, with full strength, that, in the construction of new types of paved communication routes, it was now absolutely unavoidable to follow this simple rule where roads would serve primarily to ensure, as straight as possible, communication lines between cities and other important locations from the perspective of trading opportunities.

Thirdly, it was clearly indicated how to build the roadsides of some tracks of a chaussée type. Now, "while constructing chaussée highways on the tracks of [previously made] ground roads", it was necessary to leave - but only in the event that the arrangement of natural conditions and the width of the existing natural route allowed for such a solution the remaining part of the former width of the route as a roadside, mostly for the purpose of allowing cattle (and swine) to be driven there. This "remnant" had to be kept only on one side of the former earth track. In addition, when the roadway was being constructed completely from scratch and ran along the traction line, which was not used for any transportation before, its width - and thus its off-road system - was to be constructed "according to the law", whatever that meant.

Fourthly, the legislators ordered, during the early spring of 1833, to commence roadworks, first of all, in places and locations where any repair work would prove to be particularly difficult. This was mainly said about road dykes and embankments where a significant length of the road track on which they were located was covered with wood (wooden beams), eventually where there were sloping embankments on the sides of the road, or where road builders had to deal with "[sharp or abrupt] descending [of the truck] from the mountains" etc. According to the recommendations of the new law, such parts of the road system had to be "treated slowly". Moreover, the rule in force also described a situation where the repair or replacement of these fragments at the eventual wooden road surface level, where the track was still in relatively good condition, would presumably take place only at the end of works undertaken on a given section of a communication line (but obviously only if there was such a real need and even when the relevant repair materials were at hand).

Fifthly, it was also recommended to "unhurriedly" build any stone and cast-iron road bridges (sic). What was, to some extent, truly amazing, but apparently economically reasonable at least in the eyes of tsarist legislators, the better solution was to organize such bridge constructions, whose building process would not be followed by spending any considerable financial expenses (in the original, that would have been "cheap" or rather "low cost"). Hence, it was clear that the bridges should have been as "narrow" as possible on the Muscovite roads. The priority was rather to build a proper water drainage system, i.e., a system of water drainage from the road surface level, predominantly made of stones ${ }^{15}$.

It was particularly required to respect the authorities' recommendation to proceed with the construction of new highways only and exclusively in accordance with the previously

\footnotetext{
${ }^{15}$ Petersburg Weekly: Official Gazette of Kingdom of Poland. 25 February 1834, 12: 73.
} 
developed detailed plans. Such schemes had to be drawn up separately for each route. In order to finally and formally approve such a plan as valid, it had to undergo a multistage procedure. As to the contents of the supposed road's main assumptions and plans, they mainly had to enjoy mutual understanding and acknowledgement from such important state institutions as the Ministries of the Interior and the Treasury and the Main Board for Roads of Communication and Public Edifices. Finally, it was only after initial approval of a concrete road project by St Petersburg's Committee of Ministers that the chiefs of the Ministry of the Interior and the state-owned St Petersburg-based transport authority were entitled to address the case to the so-called "Permanent Committee", which was to meet concerning any specific case about any emerging need.

In the meantime (starting with the announcement of the Act of April 1833), it was the responsibility of the Ministry of the Interior to communicate with the relevant governors/heads of governorates about where construction of "great roads" was planned, so as to solve the matter of their location, which was chosen in terms of what was most required and suitable. Another issue verified in the process of direct relations between the Ministry of the Interior and the Main Board for Roads of Communication and Public Edifices was the process of seeking some basic information about the availability of construction materials provided for specific delivery, as well as how to get them to the indicated places, along with being acquainted with other "necessary messages" on the subject. In addition, the new road law unquestionably dictated that, during preliminary works on the arrangement of detailed road plans, it was essential to consider the diverse data collected by "engineers of [the corps] of communication roads", especially those sent out to several regions of the Russian Empire on the specific order of Tsar Nicholas I. Apart from the Smolensk Governorate, these were indigenously Old Muscovite areas, i.e., governorates of Jaroslav, Tula and Ryazan.

While setting out construction plans for each individual road traction, it was critical (in accordance Article 8c of the indicated law) to: a) specify the method of financing the entire undertaking; b) divide the entire length of the road into separate parts; and c) determine the scope and manner of management of the "road departments" in each governorate. When preparing the construction plans for "great roads", everyone engaged in them was forced to follow the technical standards and rules already defined in the General Road Guide, which had been previously issued specifically for this purpose by the Main Board for Roads of Communications and Public Edifices of the Russian Empire, as well as approved by Tsar Nicholas I. In order to gain suitable insight into the exact rules of conduct in the construction of roads of the chaussée type in Russia in economic terms, the Ministry of the Interior was additionally obliged by the Law of April 1833 to issue a special instruction in this regard. Finally, the substantial strengthening of the entire main construction transport network project in the Russian Empire during the early 1830s was Count Bludov's (and subsequently Tsar Nicholas I's) order to realize the "cheaper and faster completion of roads". On the basis of this order, a special procedure was launched for the "supply" of an additional workforce, whose duties would focus on the proper implementation of this project. Namely, it was even demanded that the tsar himself (obviously not directly, but with the personal support of the Minister of War) be asked for permission to use the army for the further construction of the transportation network, especially "where it would be available to act like this" 16 .

As for the repair of the "great roads", such corrective actions could be carried out under the supervision of local governors, as well as under the general oversight of the headquarters

\footnotetext{
${ }^{16}$ Petersburg Weekly: Official Gazette of Kingdom of Poland. 25 February 1834, 12: 73-74.
} 
of St Petersburg's Ministry of the Interior. Obtaining funds necessary to achieve this objective took place via participation in tax collection, i.e., in the process of "ordinary land taxation". The particular repair tasks themselves could have been carried out in several ways: a) by conducting a formal bidding process and thus choosing a private entrepreneur to undertake the task of completing a given project; b) in "an economical way", using, for track repairs, local peasant workers who were successively used by administrative authorities for some smaller endeavours of road maintenance or even occasionally made to participate larger-scale repair works in the field of road engineering. In the first case, where it was decided to conduct a sort of public auction/tender, it was a rule that the administrative agents should provide all the needed materials to the destined work location, even before the bidding itself, and - if possible - to preserve and persist with the planned original work schedule, but only as much as "it turned out to be convenient".

Supervision over the construction and maintenance, in good shape and condition, on specific sections of these "great roads" was assigned to special officers, appointed almost solely for this purpose. These supervisors, as well as "permanent road workers", were usually accommodated "in nature", which usually meant providing them with private quarters, mostly in particular villages, but sometimes, out of necessity, in towns and cities. This and no other solution was adopted "to avoid huge costs for the construction, maintenance, lighting [candles] and heating [timber] of deliberate road station agents' houses". In those locations where, due to the relatively large distance from a given transport network, under the supervision of specific officials, to the closest but still remote site of private accommodation, it might have occurred that there was a pressing need to secure some permanent housing for communication staff. In response, the Russian authorities decided in April 1833 that "there should have been established separate, but modest housing for workers". Astonishingly enough, in Tsarist Russia at the time, it was decided not to build any specific houses for road station agents.

Despite that obvious setback in providing suitable accommodation for transportation workers, the situation was not as critical as it might have seemed at first glance. Namely, due to the anticipated wide and rapid development of the Russian transport network, as well as in relation to other crucial factors, the new law considered the possibility of building many new postal stations or houses. These decisions were to be undertaken for the purpose of solving this practical problem, which emerged when, given the new regulations for the direction and course of chaussée roads, it would have been necessary to "turn aside" from where, until the spring of 1833), post stations were firmly located. While facing such necessities, it was decided to issue new ordinances for the construction of subsequent postal edifices. Some strict rules were introduced here. Firstly, that only in the case of a higher special need (precisely, while setting the course of road roads), transport authorities could allow themselves to omit the already existing and "more significant and thoroughly constructed postal houses". Secondly, new postal houses were now ordered to be built in such a way that the transport service officials and workers could reside there, for at least some time, if not permanently. Regarding members of (higher ranks of) the road administration, the new law even indicated the possibility of providing them with some kind of permanent accommodation under the roof of newly built postal houses. Thus, it was anticipated that these premises could, at least in some aspect, connect the transport and postal services of the Russian Empire with one another. What is of significant interest regarding the possible charging of travellers (and goods) passing along newly built chaussée 
roads was the fact that lawgivers only stated, during the spring of 1833 , that "this subject will be considered later by the Ministry of the Treasury" 17 .

For the main sources of financing the construction of a new transport network in the Russian Empire during the 1830s, the April Act recognized: a) donations; b) remnants of "intended land taxation", i.e., still not included in State Treasury amounts, remaining from previously paid taxes; c) increasing the standard general level of land tax with a part intended solely for road construction; d) collection involving diverse credit institutions (without specifying the sorts and exact locations) of loans/credits, which would be secured according to the amount of state land taxes. This last activity in terms of borrowing from credit institutions would only be undertaken "for the purpose of assisting with the faster completion of chaussée roads" 18 .

Depicting, in every particular way, the phenomenon of building Russia's main transportation system, the new transportation law spoke very little about standard governorate, district, or rural roads. Thus, the processes and procedures of construction and maintenance, as well as supervision over the so-called ordinary provincial tracts, remained mostly unchanged (compared with the pre-1830s solutions) under the current rules. Even so, some exceptions to this overwhelming rule were introduced. First of all, some parts of these roads, especially those considered as "places very difficult in [terms of] maintenance and [often] requiring costly repairs", were now mandated to be remodelled as much as possible in the form of newly introduced "proper highways", instead of persistently continuing with any repairs to those existing ground roads, especially in the case of sensitive and vulnerable sections or smaller parts. It was somehow natural that such an elevation of technical standards for ordinary provincial roads, which were hither difficult to cross and maintain, could most often take place no sooner than after the completion of the basic network of local "large roads" (of course, in those governorates where no major roads were originally planned, even sooner). Secondly, within the framework of ordinary provincial roads, especially in the areas of their passage through cities and bigger towns and their localities, it was ordered to build bridges made of stone or solid iron. Such bridges were to be built "without spending unnecessary expenses" and only for the purpose of eliminating the usage of water crossings/raft transportation across rivers. Thirdly, during every stage of the construction processes of local roads with a provincial status, it was generally appropriate to adapt to the technical rules provided for the construction of "large roads".

District roads, both postal and commercial, remained under the supervision (in the original: "under the knowledge") of the governorate (land) police, which still had to supervise these types of tracks that remained completely unchanged since previous standards, terms and conditions had been introduced. Legislative bodies additionally suggested that St Petersburg's Ministry of the Interior ought to give the Permanent Committee dealing with the road engineering the opportunity to explore eventual projects for "the improvement of the rules now existing in respect of the maintenance of provincial and district roads".

Finally, maintaining "rural roads" and "field roads" still remained, by law, in the scope of the duties of local landlords or proprietors of these lands through which they passed. In the area owned by state farms, these obligations rested directly on the shoulders of the local rural population and applied "only when necessary"19.

\footnotetext{
${ }^{17}$ Petersburg Weekly: Official Gazette of Kingdom of Poland. 25 February 1834, 12: 74.

${ }^{18}$ Petersburg Weekly: Official Gazette of Kingdom of Poland. 25 February 1834, 12: 73.

${ }^{19}$ Petersburg Weekly: Official Gazette of Kingdom of Poland. 25 February 1834, 12: 74.
} 


\section{ANNOUNCMENT BY ST PETERSBURG'S COUNCIL OF STATE “ON THE MEASURES OF REALIZATION OF ROAD DUTIES", APPROVED FORMALLY BY TSAR NICHOLAS I ON 9 DECEMBER 1833/10 JANUARY 1834}

As stated above, the next step in reforming the Russian transportation network was the acceptance by Tsar Nicholas I, on 29 December 1833/10 January 1834, the opinion of St Petersburg's Council of State "on the measures of realization of roads duties", which once again had been prudently described by Count Bludov, as Minister of the Interior. The Russian Governing Senate decided to publish a new law on 25 January/6 February $1834^{20}$, which made recommendations in some respect to reintroduce former laws, but mostly introduce new legal solutions.

According to the Transportation Law of January 1834 (according to the Gregorian calendar), the implementation of new regulations was recommended especially for provincial road commissions/departments and district road commissions/departments. According to provisions of this new law, these administrative and transport bodies had to consist only of a few members. In the case of the provincial road commissions, their membership comprised: a) a civil governor as president; b) a provincial governor; c) a provincial vice governor (deputy governor); d) the administrative official managing the Cantor of the Imperial Family; e) a province surveyor. With regard to the district road commissions, their membership consisted of: a) the marshal of the district as president; b) eventually, in those areas where the district marshal did not officially function, a district judge also as president; c) "horodnicy" (Latin: "aedilis", a person responsible for provisioning cities and towns etc); d) a land "ispravnik" (the district's highest authority); e) a district surveyor ${ }^{21}$.

The release of the Transportation Act of January 1834 regarding the maintenance procedures of existing state roads in the Russian Empire dealt with many important problems. First of all, it was clearly visible, in the new regulations, that legislators assumed the possibility of improving roads as part of the process of generally maintaining transport traction in a good or adequate shape and condition. Such possibilities existed when, at the request of private landlords (here referred to as "citizens"), or at the initiative of people managing local state land properties, significant improvements were to be made to the road network, especially in places where, due to the poor basis of the tracks, frequent and significant damage to transport might have happened. In such cases, St Petersburg's Council of State allowed for the conversion - using, for that purpose, "private" money or resources of "applicants" - the existing ground routes for roads of the chaussée type, namely, paved roads. These "applicants" were also allowed to put up a "corrupted" stretch of road with packs of tied branches and all sorts of timber, i.e., poles, logs etc. The only conditions were: a) to submit a relevant request directly to St Petersburg's Minister of the Interior, b) "to prepare" the road in accordance with the provisions as contained in the instructions released for road construction. In addition to this, it was necessary to perform such works under the supervision and control of district surveys and other officials, who were "aware of this thing". As a rule, the latter were destined to participate in construction and repair works for Russian roads in the 1830 s as long as "[proper] civil engineers could be educated" 22 .

\footnotetext{
${ }^{20}$ Full Digest of Laws of the Russian Empire 1834: 817-820. St Petersburg: Printing House of Second Division of His Imperial Majesty's Chancery. Petersburg Weekly: Official Gazette of Kingdom of Poland. 18 February 1834, 10: 61.

${ }^{21}$ Petersburg Weekly: Official Gazette of Kingdom of Poland. 21 February 1834, 11: 67.

${ }^{22}$ Petersburg Weekly: Official Gazette of Kingdom of Poland. 21 February 1834, 11: 65-66.
} 
In turn, the governor of the province/governorate was personally responsible for submitting, to the Ministry of the Interior, the petition to approve the costs of repairing a "broken" provincial or district road, which apparently had to be prepared in accordance with the existing regulations (i.e., in full compliance with a list of drawings, included in the special atlas and official road building manual) by the local district/province surveyor. Such a situation could have only occurred when, at the request of local authorities/citizens, it was considered necessary to repair some longer road sections (possibly when a rather costly repair procedure was also, in specific cases, enforced for some other reasons), following the procedures described above, and with the usage of funds derived from the general budget of the governorate, eventually with the predominant addition of land taxes obtained from private citizens of a given district.

The most important part of the order of Tsar Nicholas I of 10 January 1834 to encourage making significant shortcuts in track lines (or detours) while building new "ready [to use] roads". Maintaining old solutions was only acceptable when it turned out that the so-called straightening of curvy roads (shortening the roads along a possible straight line) was associated with spending substantial amounts of money. Additionally, the possible reduction in transportation corvée ("working obligation in nature") now transpired, especially when lawgivers decided not to expect its validity in the repair of larger dams, bridges or dykes. These constructions were now regarded as objects whose maintenance required appropriate technical skills, considerable qualified construction effort and large financial outlays, which in practice meant that the local unskilled peasant population was not capable of undertaking these sorts of works. The annual repairs and possible construction of these road structures were now to be financed/carried out as a result of general land revenues from the area of a given governorate. This was implemented mostly in order to obtain better: a) effectiveness; b) working time scheduling on an annual basis. The other reason was possibly to avoid the emergence of any negative solutions that might have hampered the construction and repair work process itself.

Financial cost estimates for the construction and repair of bridges, dams and dykes were to be prepared and calculated by the main architects of the specific governorate, obviously with compulsory usage of ready-to-use technical support materials, such as formal sets of construction laws, and a set of ready-made architecture plans. Having being prepared, these estimates were presented for approval by St Petersburg's Minister of the Interior. We can also add here that bridges maintained on provincial roads had to be at least nine arshins wide (circa $6.4 \mathrm{~m}$ ), although, on district and commercial roads, their width could be significantly reduced, depending on the type of road and on the scale of the traffic on it.

The overall province budget sums, designed for necessary spending on the construction (in the original: "for the draw") of dykes, bridges and roads, could only be formally used after agreement between the Minister of the Treasury and the Minister of the Interior of the Russian Empire had been reached on this matter. It was only then that these sums were placed - along with other province expenditures - in the general local land taxation accounts ("obligations"). Every year, repair and construction work on roads, dikes and bridges, in line with the Act of January 1834, shifted to the field of activities of private entrepreneurs, who were entitled to freely participate in public tenders, held on these occasions in the respective governorate tax chambers. These tenders were carried out "according to the rules and prescribed laws".

The "road duty" (which meant the form of transportation corvée) basically referred solely to keeping tracks in good condition (in the original: "in decent condition"). In this sense, such "transportation duty" was most of all combined with any activities undertaken on 
roads, which had been already built, i.e., the processes of repair and maintenance that had to be carried out in accordance with all the existing and simultaneously practised principles. As for repairing and maintaining roads by usage of corvée duties, these had to be mostly performed by local peasants, led by "aware [of their responsibilities] and zealous officials". Obviously, the implementation of the corvée was a compulsory, non-paid burden, and only the provision of necessary building materials was to be met. The entire road network in the area of a given province, altogether with smaller bridges and less important dykes (available for building and repairing by peasants who were unprepared for this type of work), were described in detail by district surveyors. Nonetheless, the obligation to build and maintain them was divided into separate "transportation departments", i.e., consisting mainly of local residents and formal road service authorities, and distributed among residents belonging to a specific area at all social levels, on whom the corvée duty was placed to perform this obligation.

This distribution of such participation in transportation structure building, maintenance and repair had to be properly and quantitatively balanced, depending on the conditions predominant in a particular location. The legislators preferred that every inhabitant of a particular town, locality or village "enlisted for this purpose" should have done their share of the transportation duty in person, rather than by paying a hired hand to do this on their behalf. Similarly, the overwhelming current assumption was that those particular sections of the transport network that passed through specific villages, localities or towns were to be built and repaired only and exclusively by persons residing in the indicated area. In cases when there was a shortage of people capable of undertaking corvée works on the spot, the residents of neighbouring towns were also obliged to actively participate and help in the general implementation of compulsory road activities.

Considering the data given above, it became clear that the new law specified the necessity to limit the tasks of these road commissions, which until now had, in the scope of their duties, to maintain some of the more important dykes and bridges. From that time on, these transportation departments had to focus exclusively on the construction and maintenance of road traction itself. Thus it was now quite necessary to designate, for each transportation Department, the length of a communication route, which was calculated in relation to the available labour force.

In addition, referring to the functioning of these road commissions/departments, three other important recommendations were now introduced. The first of them stated that small rural private estates, whose whole area or territory was inhabited by 10 to 30 people (in the original: "souls"), were recorded in the local road commission/department archives as belonging to the larger estates or even villages. The second new legal recommendation indicated that properties inhabited by communities of up to 10 people, instead of being formally included in transportation authorities' files on any remote villages (as would have been the case from a strictly administrative division point of view), had to be assigned to the nearest located road commission. The only exception was the possibility of satisfying the request of the local estate owner himself, who might have wanted to assign his property to a more distant locality. Finally, the last innovation in this respect forced higher administrative authorities to effectively prevent the creation of one specific road commission/department, consisting only of inhabitants in the area, where only small towns and villages would be located. The introduction of such a solution was explained by the pressing need to avoid, in the future, any problems with the proper implementation of corvée service.

Besides, officially approved membership to a single road commission/department could sometimes be a highly problematic matter, especially since the new legislation allowed for 
the possibility of changing the allocation of local residents to a given transport and administration unit. This could have been done only for reasons of an independent nature and, "despite all the [preventive] measures taken", when, in some places, it was simply impossible to designate each village to a road commission/department that was relatively near to its location. In such circumstances, the Act of 10 January 1834 allowed local landowners to rely solely on their own opinion or rather common sense, and to officially suggest that the road commission, to whose responsibility their proprieties were originally assigned, would rather stretch its powers over other estates "more adjacent to the road". Such a change could take place only on the condition that contractual consent was expressed by the peasant residents of the village, whose transport jurisdiction authority was to be changed. In the area of villages formally owned by the state (namely: "[State] Treasury villages"), it was adequate to obtain a positive resolution from the whole membership of a rural cluster for this purpose; additionally, this provision had to be formally certified by its management and approved by the local tax chamber. On the other hand, in private villages, one could administratively transfer such a rural community from one road commission/department to another, only after obtaining permission from its proprietor, or private estate authorities responsible for managing the territory at stake. Regardless of whether the contract was signed for a state or private village, its content had to include a clear and unconditional statement about the acquisition of total and undisputed responsibility for maintaining local roads and bridges along routes, as well as water crossings, in good and decent conditions. This responsibility related to "residents of the entire village or estate".

The distribution of the territorial scope and duties incumbent on individual road commissions, quite naturally, could not be constant. It was inevitable, however, that, after primary establishment of the "aggregate amount of road obligation", not only would the actual technical conditions of local roads change, but the "number of [peasant] souls" remaining under the jurisdiction of individual road departments might also substantially alter. Hence, in order to maintain a possibly constant balance in the amount of corvée duties imposed, the obligation to calculate a new distribution for all of the Russian Empire's road commissions at each periodic census was now introduced. Moreover, the Law of January 1834 now required a general review by the state of all these road commissions/departments every 10 years. That demand mainly derived from the necessity for periodic review by the high tsarist authorities and existing data required to introduce a new scale of corvée obligation, to be imposed on individual road commissions over time.

In this respect, the unexpected appearance of extraordinary or exceptional events, such as resettling a significant number of peasant "souls" from one geographical area to another sometimes remote - place in Russia, and even the dislocation of whole villages, were taken into consideration. In such cases, it was expected that adequate road commissions should immediately take all the necessary steps leading to the introduction of a new scale of corvée duty. This was to be achieved on the basis of the fair and equitable distribution among existing road departments of these forced labour duties, which were originally assigned to already dislocated villages (or even entire vast areas inhabited by the rural population, which was subject the procedure of resettlement or displacement). Such a substantial change had to be accepted, on each occasion, by St Petersburg's Minister of the Interior (in 1834, this was still Count Bludov $)^{23}$.

Essential corvée works, the aim of which would be to repair roads, had naturally to take place at a time free from (other) field activities, namely, in autumn, after harvesting cereals

\footnotetext{
${ }^{23}$ Petersburg Weekly: Official Gazette of Kingdom of Poland. 21 February 1834, 11: 66.
} 
and, in spring, "after sowing the vegetables, but before haymaking". Simultaneously, the legislators allowed any other additional transportation duties to be performed during any other period convenient for the local community. However, when extraordinary incidents happened, which led to the urgent need for corrective roadworks to take place, local authorities were allowed - whether of a state administrative or private nature based on land ownership - to direct workers to carry out such corvée duties jobs, even during the time of traditional field activities such as harvesting. When any similarly extraordinary situation or accident occurred, it was requested to directly notify St Petersburg's Ministry of the Interior.

It should be noted that the very use of local manpower in preparing (verst) road signs was excluded, in January 1834, from the requirement of carrying out general construction and repair works in Tsarist Russia's transportation system. Such an official negative position was explained by the simple fact that "the construction of road signs, on the one hand, requires indispensable uniformity; on the other it would be too difficult for peasants to fulfil such a task". Having relied on this assumption, and in order to avoid inaccuracies in the implementation of roadside landmark signs, as well as the desire to prevent possible fraud resulting from the possibility of any uncontrolled money collection for this purpose, the Act of January 1834 obliged land provincial/governorate offices to prepare such roadside (verst) signs. This was quite similar to the situation regarding the construction of larger dykes and bridges, a task that had already been imposed on these provincial authorities.

Provincial and district road commissions were finally forced to undertake the extremely important administrative duty of constantly obtaining detailed and accurate data on the current "location" of all routes or ridges, dykes and water crossings within their jurisdiction. Updating this sensitive and crucial information had naturally to include a specification of this infrastructure's proprietary nature, that is, which of the above-mentioned constituents of the local transport network were maintained by usage of state revenue resources (more precisely, covered by taxpayers), and which were maintained by performing "duty in nature" 24 .

\section{CONCLUSIONS}

The introduction, in 1833 and at the turn of 1834, new transportation laws for the Russian Empire, originally developed by Count Bludov and finally approved by Tsar Nicholas I, was undoubtedly caused by growing awareness among ruling circles - especially after the Turkish and the Polish Wars - of the importance of the existence of a properly established state transport network, both for military purposes and for improving the social and economic state of the country. Despite the unquestionable importance of the matter at stake, while the task was undertaken with an appropriately formal assumption, only half measures were finally used to implement it. This is amply evidenced by repeated passages in the new legislation recommending that roadworks had to be "slowly" and "unhurriedly" conducted, as well as - most importantly - with the least financial outlay. In view of the above, the question should be asked about the planned and actual efficiency of the programme to expand the Russian transport network.

\footnotetext{
${ }^{24}$ Petersburg Weekly: Official Gazette of Kingdom of Poland. February 21, 1834, No 11: 67.
} 


\section{References}

1. Central Archives of Historical Record in Warsaw. Rada Administracyjna Królestwa Polskiego: 1832. [In Polish: The Administrative Council of the Kingdom of Poland: 1832.] Signature 24.

2. Polnoje Sobranje Zakonov Rossijskoj Imperii s 1649 goda. 1830, Vol. 30. Sankt Petersburg: Tipografia Vtorogo Otdelenja Sovstvennoj Jego Imperatorskago Velicestva Kancelarii. [In Russian: Full Digest of Laws of the Russian Empire Since 1649. 1830, Vol. 30, St Petersburg: Printing House of Second Division of His Imperial Majesty's Chancery.]

3. Polnoje Sobranje Zakonov Rossijskoj Imperii, Sobranje Vtoroje. 1834, Vol. 8. Sankt Petersburg: Tipografia Vtorogo Otdelenja Sovstvennoj Jego Imperatorskago Velicestva Kancelarii. [In Russian: Full Digest of Laws of the Russian Empire. 1834, Vol. 8. St Petersburg: Printing House of Second Division of His Imperial Majesty's Chancery.]

4. Tygodnik Petersburski. Gazeta Urzędowa Królestwa Polskiego. [[In Polish: Petersburg Weekly: Official Gazette of Kingdom of Poland.] 18 February 1834, 10. St Petersburg: J.E. Przecławski.

5. Tygodnik Petersburski. Gazeta Urzędowa Królestwa Polskiego. [In Polish: Petersburg Weekly: Official Gazette of Kingdom of Poland. St Petersburg: J.E. Przecławski.] 21 February 1834, 11.

6. Varadinov N. 1862. Istoria Ministerstva Vnutriennich Del. Cast 3. Kniga 1. St Petersburg. V ipografii Ministsrstva Vnutriennych del. [In Russian: History of the Ministry of the Interior. St Petersburg: Printing House of Ministry of the Interior.]

Received 02.04.2018; accepted in revised form 30.08.2018

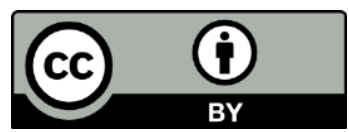

Scientific Journal of Silesian University of Technology. Series Transport is licensed under a Creative Commons Attribution 4.0 International License 